\title{
INTRODUCCIÓN \\ EN EL CENTENARIO DE CREACIÓN DEL INSTITUTO-ESCUELA. LOS CENTROS PÚBLICOS INTEGRADOS DE EDUCACIÓN PRIMARIA Y SECUNDARIA OBLIGATORIA: Pervivencia del pensamiento de Francisco Giner de los Ríos y de los principios de la ILE
}

http://dx.doi.org/10.15304/ie.28.5521

\author{
Raquel Vázquez Ramil \\ Universidad de Valladolid \\ mariaraquel.vazquez@uva.es \\ Ángel Serafín Porto Ucha \\ Universidade de Santiago de Compostela \\ angelserafin.porto@usc.es
}

El 19 de mayo de 1918, en el contexto de las realizaciones educativas de los institucionistas y con carácter de ensayo pedagógico para la reforma del Bachillerato, Santiago Alba firmó el decreto de creación del Instituto-Escuela de Madrid. Respondía a la idea gineriana de continuación entre la primera y la segunda enseñanza. Este ensayo se puso en manos de la Junta para Ampliación de Estudios e Investigaciones Científicas (JAE), siendo su contenido central la problemática de la Segunda Enseñanza, el bachillerato único o múltiple, los Planes de estudios, los métodos, etc.

En el ideario pedagógico de Francisco Giner de los Ríos (1839-1915), creador de la Institución Libre de Enseñanza (ILE), figuraba la educación como actividad formadora integral, donde entre otras cuestiones (neutralidad, coeducación, no a los libros de texto), se buscaba la continuidad de los estudios de primera y segunda enseñanza. Francisco Giner defendía sólo dos niveles de enseñanza: una enseñanza general, que había de comprender la primera y la segunda enseñanza, y una enseñanza especial, profesional o superior (Porto Ucha, 2011: 407-410).

Con la creación de la Institución Libre de Enseñanza (1876), una síntesis de su propuesta nos la ofrece un Prospecto para el curso 1885-86 (BILE, IX (1885), p. 285):

1. Los alumnos no estudian asignaturas aisladas, sino que se dividen por secciones, conforme al grado de su desarrollo, y lo menos numerosas posibles, para que el maestro pueda comunicar diariamente con todos sus discípulos y hacerles tomar parte activa en el trabajo.

2. Por lo que se refiere al programa, la enseñanza es cíclica. No existe la absoluta separación usual entre la educación de párvulos, la primaria y la secundaria, sino que estos tres grados constituyen un solo: el de la educación general. Los diversos estudios marchan paralelamente: el niño aprende las mismas cosas en la primera sección que en la última; sólo comenzando con las líneas y puntos capitales en cada materia y afirmándolas y desdoblándolas progresivamente.

Esta idea se mantuvo en el tiempo. En el Programa de 1934 (BILE, LVIII (1934), pp. 8794), en el apartado de «Principios y Orientaciones», junto con el sentido de la educación, la cultura 


\section{RAQUEL VÁZQUEZ RAMIL, ÁNGEL SERAFÍN PORTO UCHA: Introducción}

general, el juego, la protesta contra el sistema corruptor de exámenes, la coeducación, los libros de texto, las excursiones, la activa colaboración con las familias, se añade que «no existe la separación usual entre la escuela de párvulos, la primaria y la secundaria, sino que estos tres períodos constituyen uno solo y continuo: el de la educación general».

La Institución Libre de Enseñanza defendió una organización escolar en la que los distintos grados de enseñanza estaban interrelacionados. No existían diferencias entre el profesorado de la clase de párvulos y el de los universitarios. La metodología seguida impregnaba todo el hacer de la Institución. En ese sentido, encontramos en la ILE una concepción innovadora del sistema educativo frente a la clásica división de los distintos niveles: Unión de la primera y la segunda enseñanza (incluso los párvulos). Fusión. Sistema cíclico, ganando progresivamente en extensión y profundidad (Porto Ucha, 2005:142-143).

En los sesenta años de existencia de la ILE (1876-1936) se pueden considerar tres períodos: el primero, de apertura liberal, terminó en 1881. Coincide con la llegada de José Luis Albareda al Ministerio de Fomento y la vuelta a sus cátedras de los profesores deportados con motivo de la política retrógrada de Orovio en los comienzos de la Restauración. El segundo período ocupa el último tercio del siglo XIX, hasta la fundación de la Junta para Ampliación de Estudios e Investigaciones Científicas en 1907. Durante este período tienen lugar toda una serie de incursiones político-sociales de los institucionistas. Con la creación de la Junta para Ampliación de Estudios, que va a ejercer su influencia dentro del aparato del Estado, se inaugura para la Institución Libre una tercera época que alcanza hasta 1936, con la ruptura de la guerra civil. Dependientes del Estado, fueron haciendo su aparición una serie de organismos de base institucionista, entre ellos el InstitutoEscuela, incardinado en el esquema de la JAE.

El plan de estudios del Instituto-Escuela defendía la continuidad en el estudio por materias, con programas cíclicos y estudios comunes y obligatorios, que permitían la especialización en los dos últimos cursos. Además de las materias cursadas en los demás institutos, se incluían otras nuevas como el griego, lenguas modernas, enseñanzas artísticas, trabajos manuales y música.

Las bases de dicho plan eran: a) cultura general, elemental, extensa, sin finalidad utilitaria ni profesional, en forma cíclica; b) concesión de un cierto margen a las preferencias individuales. El alumnado se distribuyó en dos secciones: una de carácter preparatorio -en la que tuvo un papel principal María de Maeztu Withney, directora asimismo de la Residencia de Señoritas de Madrid (Vázquez Ramil, 2012; Porto Ucha y Vázquez Ramil, 2015)-, para alumnos y alumnas de 8 a 10 años, y otra, propiamente Bachillerato, con cuatro grados de estudio comunes y otros dos selectivos, de 11 a 16 años. El profesorado estaba compuesto por catedráticos numerarios de instituto, maestros y maestras de grado superior y aspirantes a la enseñanza secundaria.

El 29 de enero de 1925 la JAE envió al Ministerio de Instrucción Pública un informe, tras el que se insertaron unas líneas generales, que servirían de orientación para implantar el ensayo del Instituto-Escuela. En el informe se recogen los resultados de los seis primeros cursos escolares de ensayos y se pone de relieve que se trata de un centro de experimentación creado para la reforma de la Segunda Enseñanza. Era un Instituto con carácter de «laboratorio pedagógico». A partir del 1 de marzo de 1930, el Instituto-Escuela adquirió carácter permanente. 
Con la llegada de la Segunda República, esta innovación se extendió a otras ciudades. El Ministerio autorizó a la Generalitat de Cataluña para organizar en Barcelona un Instituto-Escuela semejante al de Madrid (Decreto de 9/10/1931). Por otro Decreto de 2/3/1932, con Fernando de los Ríos como Ministro de Instrucción Pública, se crearon Institutos-Escuela en Valencia y Sevilla. La O.M. de 17/2/1933 creaba el Instituto-Escuela de Málaga. A ellos siguieron otros en Barcelona y Gijón. Hubo, además, intentos como el de Granada.

La guerra civil y el franquismo dieron al traste con esta innovadora experiencia.

Ya en el período democrático posterior a la proclamación de la Constitución de 1978, la Ley de Ordenación General del Sistema Educativo (LOGSE, 1990), y disposiciones posteriores, con la ampliación de la escolaridad obligatoria a 10 años (educación básica, 6-16 años) y las dificultades de transición entre la educación primaria y la secundaria, se recuperó esa iniciativa, a través de la creación de los centros públicos integrados de educación primaria y secundaria obligatoria, incluyendo, en su caso, también la educación infantil (gratuita, 3-6 años). Porque en los centros privados (concertados o no) nunca dejó de haber esa posibilidad, aunque con preocupaciones e intereses distintos y diferentes casuísticas. Los centros integrados ofrecen indudables ventajas, pero también presentan dificultades, entre ellas el desarrollo de los respectivos reglamentos orgánicos (con la presencia de dos jefes de estudios), o «el desarrollo de las culturas profesionales diferentes» (Andrés Rubia, 2011), concepto al que le ha prestado atención Viñao (2002), en cuanto a la cultura escolar de los maestros y de los profesores de secundaria. No tratamos aquí el tema de los Centros Integrados Públicos de Formación Profesional.

Entre otras experiencias, como es el caso de Aragón, que Fernando Andrés Rubia analiza en este número de Innovación Educativa, «en dos comunidades eminentemente rurales como Galicia y Castilla y León este fue el modelo necesario que arranca la implantación de la LOGSE». En comunidades como Madrid «es un modelo más bien anecdótico, motivado la mayor parte de las veces por cuestiones organizativas y económicas». En Cataluña, «la apuesta data de la Ley de Educación de Cataluña (2009)» (Saray Marqués, 2018).

La prensa también se ha hecho eco de esta problemática, y a través de ella es posible realizar un estudio de estos centros, con una metodología que hemos utilizado en otras ocasiones (Porto Ucha, 2003; Mera Cao, 2014). Así, en Galicia, el modelo CPI fue pensado «para los concellos rurales donde no compensa montar un IES pero tampoco conviene que los alumnos de 12 años pasen horas en el bus para ir a otro concello» (La Voz de Galicia, 30/6/2017).

Con motivo del centenario de creación del Instituto-Escuela (1918-2018) Innovación Educativa pensó en la posibilidad de dedicar un monográfico al estudio de esta experiencia, tanto desde el punto de vista histórico-educativo, focalizado en el análisis de los Institutos-Escuela anteriores a la contienda civil, como estudiando los centros públicos de estas características puestos en funcionamiento en las distintas comunidades autónomas, básicamente con la llegada del nuevo siglo, en sus diversas denominaciones y presupuestos. Se trata sólo de una aproximación. Somos conscientes de que el tema merecería un estudio global más amplio, con la participación de las instituciones educativas del conjunto de las comunidades autónomas del Estado español. 
El tema principal de este número de la revista Innovación Educativa ocupa, pues, dos tipos de trabajos:

\section{a) Los referidos a los Institutos-Escuela históricos}

Este apartado comprende tres artículos. Uno de carácter general, de Ángel Serafín Porto Ucha y Raquel Vázquez Ramil, «En el centenario de creación del Instituto-Escuela: Realizaciones educativas de los institucionistas», en el que se repasan las iniciativas pedagógicas de la ILE, dedicando especial atención al Instituto-Escuela de Madrid, que este año celebra su centenario; asimismo, se presta atención a la huella que los proyectos pedagógicos institucionistas dejaron en Galicia, con ejemplos como la Misión Biológica o las colonias escolares.

Encarnación Martínez Alfaro ofrece, en «Tiempo y memoria del Instituto Escuela de Madrid» un documentado análisis de la creación del Instituto-Escuela de Madrid, concretamente la llamada sección Retiro, junto al famoso parque, y su conversión tras la guerra civil en IES Isabel la Católica. Encarnación Martínez Alfaro, catedrática de Geografía e Historia en dicho centro, ha estudiado a fondo la documentación histórica existente en el mismo y ofrece también la utilización del patrimonio del Instituto-Escuela como recurso didáctico con alumnos de ESO, experiencias sumamente interesantes y que vinculan un pasado olvidado durante mucho tiempo con la realidad pedagógica actual más vibrante.

Patricia Delgado Granados, profesora de Teoría e Historia de la Educación de la Universidad de Sevilla, presenta «El Instituto-Escuela de Sevilla (1932-1936): Un proyecto inconcluso de renovación pedagógica en España» y analiza la apertura del Instituto-Escuela en la capital hispalense, en tiempos de la Segunda República, y su traumático cierre con la guerra civil, como todas las empresas de esta índole.

\section{b) Los referidos a los actuales centros públicos integrados de educación primaria y secundaria}

En este apartado contamos con el estudio de Fernando Andrés Rubia, maestro y sociólogo y director de las revistas Forum Aragón y Organización y Gestión Educativa, «Impulso y resistencia en la creación de centros integrados en Aragón». Fernando Andrés ha estudiado a fondo la cuestión de los centros públicos integrados en Aragón y presenta un estudio muy bien fundamentado sobre sus posibilidades y también los retos que plantean estos centros, no siempre bien asumidos.

Màrius Martínez Muñoz, profesor de Orientación Profesional en la Universidad Autónoma de Barcelona, y Carmina Pinya Salomó, docente e investigadora, contribuyen con el artículo «Los Institutos-Escuela en Catalunya: recuperando la mejor tradición pedagógica de la República», en el que ofrecen una interesante perspectiva sobre el modelo de centro público integrado de Cataluña, que desde el año 2009 recupera el nombre histórico de Instituto-Escuela, y su trayectoria.

El ámbito de Galicia es analizado por Julia $\mathrm{M}^{\mathrm{a}}$ Diz López, miembro del Departamento de Pedagogía y Didáctica de la Universidad de Santiago de Compostela, en el artículo titulado «Los centros públicos integrados en Galicia. Un modelo a debate», donde se exponen con claridad los debates que generan actualmente este tipo de centros en la Comunidad Autónoma gallega. Y en esta línea, pero con un estudio de caso, la profesora Ana $\mathrm{M}^{\mathrm{a}}$ Porto Castro, también del Departamento 
de Pedagogía y Didáctica de la Universidad de Santiago de Compostela, e Isabel Sánchez Manso, exdocente en un centro público integrado, presentan «Pasado y presente de un Centro Público Integrado de Galicia», donde analizan el caso del CPI Viaño Pequeno de Trazo (A Coruña). Estos dos artículos referidos a Galicia se complementan con el estudio de Enelina $\mathrm{M}^{\mathrm{a}}$ Gerpe García, «Panorámica actual de los centros públicos integrados de enseñanza obligatoria en la Comunidad Autónoma de Galicia», incluido en la sección de Documentación.

Esperamos, con este número 28 de la revista Innovación Educativa, conmemorar el centenario del primer Instituto-Escuela, creado por la JAE en Madrid en 1918, y situarnos en el presente, analizando la realidad de los centros públicos que pretenden integrar la enseñanza primaria y secundaria en un solo centro, sus perspectivas de futuro y los retos que plantean.

\section{REFERENCIAS BIBLIOGRÁFICAS}

Andrés Rubia, F. (2011). Los centros públicos integrados de enseñanza obligatoria: un territorio inexplorado. Fórum Aragón, 3 (octubre), 3-7.

Las claves del conflicto en Educación. El modelo de colegio integrado gusta mucho a las familias, pero no al Estado. La Voz de Galicia, 30/6/2017.

Marqués, S. (2018). Centros integrados: cuando la pública imita a la concertada. El diario de la educación, 8/5/2018.

Mera Cao, F. (2014). O conflito nos centros escolares. Imaxe da conflitividade escolar na prensa. TFG. USC. Facultade de Ciencias da Educación, Dpto. de Didáctica e Organización Escolar. Grao en Educación Primaria. Tutor: Ángel Serafín Porto Ucha.

Porto Ucha, A. S. (2003). La imagen de la conflictividad en la prensa gallega. En E. López-Barajas Zayas, y J. H. Bouché Peris (Coords.), La educación para una cultura de paz: Problemas y perspectivas. Madrid: UNED, pp. 258-262.

Porto Ucha, A. S. (2005). La Institución Libre de Enseñanza y la renovación pedagógica en Galicia. Sada - A Coruña: Ediciós do Castro.

Porto Ucha, A. S. (2011). La Institución Libre de Enseñanza. Un movimiento de renovación pedagógica. En O. Negrín Fajardo, Historia de la Educación Española. Madrid: UNED, pp. 383-427.

Porto Ucha, A. S. y Vázquez Ramil, R. (2015). María de Maeztu. Una antología de textos. Madrid: Dykinson.

Prospecto para el curso de 1885-86, BILE, IX (1885), p. 285.

Programa de la Institución Libre de Enseñanza. BILE, LVIII (1934), pp. 87-94.

Vázquez Ramil, R. (2012). Mujeres y educación en la España contemporánea. La Residencia de Señoritas de Madrid (1915-1936). Madrid: Akal.

Viñao, A. (2002). Sistemas educativos, culturas escolares y reformas. Madrid: Morata.

\section{Legislación}

Galicia. Consellería de Educación y Ordenación Universitaria. Decreto 7/1999, de 7 de enero (DOG, $n^{\circ} 16$, de 26/01/1999), por el que se implantan y regulan los centros públicos integrados de enseñanzas non universitarias. 



\title{
INTRODUCTION \\ IN THE CENTENARY OF THE INSTITUTE-SCHOOL CREATION. THE INTEGRATED PUBLIC SCHOOLS OF COMPULSORY PRIMARY AND SECONDARY EDUCATION: Persistence of the Francisco Giner de los Ríos' thought and of the ILE' principles
}

\author{
Raquel Vázquez Ramil \\ University of Valladolid \\ mariaraquel.vazquez@uva.es \\ Ángel Serafín Porto Ucha \\ University of Santiago de Compostela \\ angelserafin.porto@usc.es
}

On May 19 of 1918, in the context of the institutionists' educational achievements and as a pedagogical essay for the reform of the baccalaureate, Santiago Alba signed the decree creating the Institute-School of Madrid. The initiative responded to the Giner' idea of continuation between the primary and the secondary education. This essay was implemented by the Board for the Extension of Studies and Scientific Investigations, being its core the problem of the second education, a single or a multiple baccalaureate, the syllabuses, the methods, etc.

In the pedagogical ideology of Francisco Giner de los Ríos (1839-1915), soul of the Institución Libre de Enseñanza or Free Institution for Education (ILE), education was an integral training activity, where among other issues (neutrality, coeducation, teaching without textbooks), the continuity between primary and secondary education was a goal. Francisco Giner defended only two education levels: a general education, embracing primary and secondary education, and a special education, with professional or higher character (Porto Ucha, 2011: 407-410).

With the creation of the Institución Libre de Enseñanza (1876), a synthesis of his proposal is offered to us by a Prospectus for the 1885-86 academic year (BILE, IX (1885), page 285):

1. The students do not study isolated subjects, but they are divided by sections, according to the degree of their development, and the least numerous possible, so that the teacher can communicate daily with all his disciples and make them take an active part in the work.

2. As regards the program, teaching is cyclical. There isn't the usual and absolute separation between kindergarten, primary and secondary education, but these three degrees constitute a single unit: that of general education. The various studies run in parallel: the child learns the same things in the first section as in the last one; only starting with the lines and capital points in each subject, affirming and progressively unfolding them.

This idea remained in time. In the Program of 1934 (BILE, LVIII (1934), pp. 87-94), in the section "Principles and Guidance", together with the sense of education, general culture, the game, the protest against the corrupted system of examinations, coeducation, textbooks, field trips, active 
collaboration with families, it is added that «there isn't the usual separation between kindergarten, primary and secondary school, but these three periods constitute one alone and continuous: that of general education».

The Institución Libre de Enseñanza defended a school organization in which the different levels of education were interrelated. There were no differences between the teachers in the kindergarten class and the university class. The methodology followed impregnated all the work of the Institution. In this sense, we find in the ILE an innovative conception of the educational system in front of the classic division in different levels: union of the first and the second education (even the kindergartners). Fusion. Cyclical system, progressively gaining in extension and depth (Porto Ucha, 2005: 142-143).

In the sixty years of existence of the ILE (1876-1936) three periods can be considered: the first, of liberal opening, ended in 1881. It coincides with the arrival of José Luis Albareda to the Ministry of Development and the return to their chairs of the professors dismissed on the occasion of the Orovio's retrograde policy at the beginning of the Restoration. The second period occupies the last third of the nineteenth century, until the founding of the Board for the Extension of Studies and Scientific Research (JAE) in 1907. During this period a whole series of socio-political incursions of the institutionists took place. With the creation of the Board for the Extension of Studies, which will exercise its influence within the State apparatus, the Institución Libre inaugurates a third period that reaches until 1936, with the rupture of the civil war. Dependents of the State, were making their appearance a number of agencies of institutionist character, including the Institute-School, incardinated in the scheme of the $J A E$.

The curriculum of the Institute-School defended the continuity in the study by subjects, with cyclical programs and common and obligatory studies, which allowed the specialization in the last two courses. In addition to the subjects studied in the other institutes, new ones were included, such as Greek, Modern Languages, Artistic Education, Arts and Crafts, and Music. The bases of such a plan were: a) general, elementary, extensive culture, without utilitarian or professional purpose, in a cyclical way; b) granting a certain margin to individual preferences. The students were divided into two sections: one of a preparatory nature-in which Maria de Maeztu Withney had a leading role, also Principal of the Residencia de Señoritas or Residence for Women Students of Madrid (Vázquez Ramil, 2012, Porto Ucha and Vázquez Ramil, 2015)-, for students from 8 to 10 years old; and another, properly Baccalaureate, with four common study levels and two selective ones, from 11 to 16 years old. The faculty was made up of university full-time professors, teachers of higher education and assistant professors of secondary education.

On January 29 of 1925 the $J A E$ sent a report to the Ministry of Public Instruction, after which some general lines were inserted, which would serve as guidance to implement the InstituteSchool essay. The report includes the results of the first six school years of trials and highlights that it is an experimental center created for the reform of the Second Teaching. It was an Institute with the character of «pedagogical laboratory». After March 1 of 1930, the Institute-School became permanent. 
With the arrival of the Second Republic, this innovation spread to other cities. The Ministry authorized the Generalitat of Catalonia to organize in Barcelona an Institute-School similar to that of Madrid (Decree of 9/10/1931). By another Decree of 2/3/1932, being Fernando de los Ríos Minister of Public Instruction, Institute-Schools were created in Valencia and Seville. The OM of 2/17/1933 created the Institute-School of Málaga. They were followed by others in Barcelona and Gijón. There were also attempts, like the one in Granada.

The Civil War and the Franco regime put an end to this innovative experience.

In the democratic period, after the 1978 Constitution, the Law of General Regulation of the Educational System (LOGSE, 1990), and subsequent provisions, with the extension of compulsory education to 10 years (basic education, from 6 to 16 years old) and the difficulties of transition between primary and secondary education, this initiative was recovered, through the creation of integrated public primary and secondary education centers, including, where appropriate, also early childhood education (free, from 3 to 6 years old). In private centres (concerted or not) the possibility never ceased, although with different concerns and interests and different casuistry. The integrated centers offer undoubted advantages, but they also present difficulties, among them the development of the respective organic regulations (with the presence of two heads of studies, for instance), or «the development of different professional cultures» (Andrés Rubia, 2011), a concept considered by Viñao (2002), who has analyzed the school culture of primary teachers and high school teachers. We are not dealing here with the issue of Integrated Public Vocational Training Centers.

Among other experiences, as is the case of Aragon, that Fernando Andrés Rubia analyzes in this issue of Innovación Educativa, «in two eminently rural communities such as Galicia and Castile-Leon, this was the necessary model that started with the implementation of the LOGSE». In communities like Madrid «it is a rather anecdotal model, motivated most of the time by organizational and economic issues». In Catalonia, «the bet dates from the Education Law of Catalonia (2009)» (Saray Marqués, 2018).

The media have also echoed this problem, and it is possible to carry out a study of these centers, with a methodology that we have used on other occasions (Porto Ucha, 2003; Mera Cao, 2014). Thus, in Galicia the CPI model was designed «for rural villages where it is not worth setting up an IES, but it is also not convenient for 12-year-old students to spend hours on the bus to go to another town», (La Voz de Galicia, 30/06/2017).

On the occasion of the centenary of the creation of the Institute-School (1918-2018), Innovación Educativa considered the possibility of dedicating a monographic issue to the study of this experience, both from the historical-educational point of view, focused on the analysis of the Institutes-School prior to the civil conflict, and also studying the public centers of these characteristics opened in the different autonomous communities, basically with the arrival of the new century, in its various denominations and concepts. It is only an approach. We are aware that the topic deserves a broader global study, with the participation of the educational institutions of all the autonomous communities of the Spanish State.

The main theme of this issue of the journal Innovación Educativa embraces, then, two types of contributions: 


\section{a) Those referred to the historical Institutes-Schools}

This section comprises three articles. One of a general nature, by Ángel Serafín Porto Ucha and Raquel Vázquez Ramil, «In the Centenary of the Institute - School: Institutionism' Educational Accomplishments», in which the pedagogical initiatives of the ILE are reviewed, paying special attention to the Institute -School of Madrid, which celebrates its centenary this year; Likewise, attention is paid to the footprint that institutionalist pedagogical projects left in Galicia, with examples such as the Biological Mission or the school colonies.

Encarnación Martínez Alfaro offers, in «Time and memory of the Institute-School», a documented analysis of the creation of the Institute-School of Madrid, specifically the so-called Retiro section, next to the famous park, and its conversion after the civil war in IES Isabel la Católica. Encarnación Martínez Alfaro, Professor of Geography and History at the center, has thoroughly studied the historical documentation in it and also offers the use of the Institute-School heritage as a teaching resource with ESO students, extremely interesting experiences and link a past forgotten for a long time with the more vibrant current pedagogical reality.

Patricia Delgado Granados, Associate Professor of Theory and History of Education at the University of Seville, presents «The Institute-School of Seville (1932-1936): An unfinished project of pedagogical renovation in Spain» and analyzes the opening of the Institute-School in the capital of Seville, at the time of the Second Republic, and its traumatic closure with the civil war, like all initiatives of this kind.

\section{b) Those referred to current public integrated primary and secondary education centers}

In this section we have the study of Fernando Andrés Rubia, teacher, sociologist and editor of the journals Forum Aragón and Organización y Gestión Educativa, «Impulse and resistance in the creation of integrated centres in Aragon». Fernando Andrés has studied in depth the question of integrated public centres in Aragon and presents a well-founded study on its possibilities and also the challenges posed by these centres, not always well assumed.

Màrius Martínez Muñoz, professor of Professional Guidance at the Autonomous University of Barcelona, and Carmina Pinya Salomó, teacher and researcher, contribute with the article «The Institute-Schools in Catalonia: recovering the best pedagogical tradition of the Republic», in which they offer an interesting perspective on the integrated public model of centre in Catalonia, which since 2009 has recovered the historical name of Instituto-Escuela, and its trajectory.

The scope of Galicia is analyzed by Julia $\mathrm{M}^{\mathrm{a}} \mathrm{Diz}$ López, member of the Department of Pedagogy and Didactics of the University of Santiago de Compostela, in the article entitled «Integrated public centres in Galicia. A model to debate», where the debates that generate these types of centres in the Galician Autonomous Community are clearly exposed.

And in this line, but with a case study, Professor Ana Ma Porto Castro, also from the Department of Pedagogy and Didactics of the University of Santiago de Compostela, and Isabel Sánchez Manso, former teacher in an integrated public centre, sign «Past and present of an Integrated Public Centre of Galicia», where they analyse the case of the CPI Viaño Pequeno de Trazo (A Coruña). 
These two articles referring to Galicia are complemented by the study by Enelina $\mathrm{M}^{\mathrm{a}}$ Gerpe García, «Current overview of the integrated public centres of compulsory education in the Autonomous Community of Galicia», included in the Section of Documentation.

We hope, with this issue 28 of Innovación Educativa, to commemorate the centenary of the first Institute-School, created by the JAE in Madrid in 1918, and situate ourselves in the present, analysing the reality of the public centres that intend to integrate primary education and secondary in a single centre, their future prospects and the challenges they pose.

\section{REFERENCES}

Andrés Rubia, F. (2011). Los centros públicos integrados de enseñanza obligatoria: un territorio inexplorado. Fórum Aragón, 3 (octubre), 3-7.

Las claves del conflicto en Educación. El modelo de colegio integrado gusta mucho a las familias, pero no al Estado. La Voz de Galicia, 30/6/2017.

Marqués, S. (2018). Centros integrados: cuando la pública imita a la concertada. El diario de la educación, 8/5/2018.

Mera Cao, F. (2014). O conflicto nos centros escolares. Imaxe da conflitividade escolar na prensa. TFG. USC. Facultade de Ciencias da Educación, Dpto. de Didáctica e Organización Escolar. Grado en Educación Primaria. Tutor: Ángel Serafín Porto Ucha.

Porto Ucha, A. S. (2003). La imagen de la conflictividad en la prensa gallega. En E. López-Barajas Zayas, y J. H. Bouché Peris (Coords.), La educación para una cultura de paz: Problemas y perspectivas. Madrid: UNED, pp. 258-262.

Porto Ucha, A. S. (2005). La Institución Libre de Enseñanza y la renovación pedagógica en Galicia. Sada - A Coruña: Ediciós do Castro.

Porto Ucha, A. S. (2011). La Institución Libre de Enseñanza. Un movimiento de renovación pedagógica. En O. Negrín Fajardo: Historia de la Educación Española. Madrid: UNED, pp. 383-427.

Porto Ucha, A. S. y Vázquez Ramil, R. (2015). María de Maeztu. Una antología de textos. Madrid: Dykinson.

Prospecto para el curso de 1885-86, BILE, IX (1885), p. 285.

Programa de la Institución Libre de Enseñanza. BILE, LVIII (1934), pp. 87-94.

Vázquez Ramil, R. (2012): Mujeres y educación en la España contemporánea. La Residencia de Señoritas de Madrid (1915-1936). Madrid: Akal.

Viñao, A. (2002): Sistemas educativos, culturas escolares y reformas. Madrid: Morata.

\section{Laws}

Galicia. Consellería de Educación y Ordenación Universitaria. Decreto 7/1999, de 7 de enero (DOG, $\mathrm{n}^{\mathrm{o}} 16$, de 26/01/1999), por el que se implantan y regulan los centros públicos integrados de enseñanzas non universitarias. 



\title{
INTRODUCIÓN \\ NO CENTENARIO DE CREACIÓN DO INSTITUTO-ESCUELA. OS CENTROS PÚBLICOS INTEGRADOS DE EDUCACIÓN PRIMARIA \\ E SECUNDARIA OBRIGATORIA: Pervivencia do pensamento de Francisco Giner de los Ríos e dos principios da ILE
}

\author{
Raquel Vázquez Ramil \\ Universidade de Valladolid \\ mariaraquel.vazquez@uva.es \\ Ángel Serafín Porto Ucha \\ Universidade de Santiago de Compostela \\ angelserafin.porto@usc.es
}

O 19 de maio de 1918, no contexto das realizacións educativas dos institucionistas e con carácter de ensaio pedagóxico para a reforma do Bacharelato, Santiago Alba asinou o decreto de creación do Instituto-Escuela de Madrid. Respondía á idea gineriana de continuación entre a primeira e a segunda ensinanza. Este ensaio púxose en mans da Junta para Ampliación de Estudios e Investigaciones Científicas (JAE), sendo o seu contido central a problemática da Segunda Ensinanza, o bacharelato único ou múltiple, os Plans de estudos, os métodos, etc.

No ideario pedagóxico de Francisco Giner de los Ríos (1839-1915), creador da Institución Libre de Enseñanza (ILE), figuraba a educación como actividade formadora integral, onde entre outras cuestións (neutralidade, coeducación, non aos libros de texto), buscábase a continuidade dos estudos de primeira e segunda ensinanza. Francisco Giner defendía só dous niveis de ensinanza: unha ensinanza xeral, que había de comprender a primeira e a segunda ensinanza, e unha ensinanza especial, profesional ou superior (Porto Ucha, 2011: 407-410).

Coa creación da Institución Libre de Enseñanza (1876), unha síntese da súa proposta ofrécenola un Prospecto para o curso 1885-86 (BILE, IX (1885), p. 285):

1. Los alumnos no estudian asignaturas aisladas, sino que se dividen por secciones, conforme al grado de su desarrollo, y lo menos numerosas posibles, para que el maestro pueda comunicar diariamente con todos sus discípulos y hacerles tomar parte activa en el trabajo.

2. Por lo que se refiere al programa, la enseñanza es cíclica. No existe la absoluta separación usual entre la educación de párvulos, la primaria y la secundaria, sino que estos tres grados constituyen un solo: el de la educación general. Los diversos estudios marchan paralelamente: el niño aprende las mismas cosas en la primera sección que en la última; sólo comenzando con las líneas y puntos capitales en cada materia y afirmándolas y desdoblándolas progresivamente.

Esta idea mantívose no tempo. No Programa de 1934 (BILE, LVIII (1934), pp. 87-94), no apartado de «Principios y Orientaciones», xunto co sentido da educación, a cultura xeral, o xogo, a protesta contra o sistema corrompido dos exames, a coeducación, os libros de texto, as excursións, 
a activa colaboración coas familias, engádese que «no existe la separación usual entre la escuela de párvulos, la primaria y la secundaria, sino que estos tres períodos constituyen uno solo y continuo: el de la educación general»».

A Institución Libre de Enseñanza defendeu unha organización escolar na que os distintos graos de ensinanza estaban interrelacionados. Non existían diferenzas entre o profesorado da clase de párvulos e o dos universitarios. A metodoloxía seguida impregnaba todo o facer da Institución. Nese sentido, encontramos na ILE unha concepción innovadora do sistema educativo fronte á clásica división dos distintos niveis: Unión da primeira e da segunda ensinanza (incluso os párvulos). Fusión. Sistema cíclico, gañando progresivamente en extensión e profundidade (Porto Ucha, 2005:142-143).

Nos sesenta anos de existencia da ILE (1876-1936) pódense considerar tres períodos: o primeiro, de apertura liberal, rematou en 1881. Coincide coa chegada de José Luis Albareda ao Ministerio de Fomento e a volta ás súas cátedras dos profesores deportados con motivo da política retrógrada de Orovio nos comezos da Restauración. O segundo período ocupa o último terzo do século XIX, ata a fundación da Junta para Ampliación de Estudios e Investigaciones Científicas en 1907. Durante este período teñen lugar toda unha serie de incursións político-sociais dos institucionistas. Coa creación da Junta para Ampliación de Estudios, que vai exercer a súa influencia dentro do aparato do Estado, inaugúrase para a Institución Libre unha terceira época que acada ata 1936, coa ruptura da guerra civil. Dependentes do Estado, van facendo a súa aparición unha serie de organismos de base institucionista, entre eles o Instituto-Escuela, incardinado no esquema da JAE.

O plan de estudos do Instituto-Escuela defendía a continuidade no estudo por materias, con programas cíclicos e estudos comúns e obrigatorios, que permitían a especialización nos dous últimos cursos. Ademais das materias cursadas nos demais institutos, incluíanse outras novas coma o grego, linguas modernas, ensinanzas artísticas, traballos manuais e música.

As bases de dito plan eran: a) cultura xeral, elemental, extensa, sen finalidade utilitaria nin profesional, en forma cíclica; b) concesión dunha certa marxe ás preferencias individuais. $\mathrm{O}$ alumnado distribuíuse en dúas seccións: unha de carácter preparatorio, na que tivo un papel principal María de Maeztu Withney, directora así mesmo da Residencia de Señoritas de Madrid (Vázquez Ramil, 2012; Porto Ucha e Vázquez Ramil, 2015), para alumnos e alumnas de 8 a 10 anos, e outra, propiamente Bacharelato, con catro graos de estudo comúns e outros dous selectivos, de 11 a 16 anos. O profesorado estaba composto por catedráticos numerarios de instituto, mestres e mestras de grao superior e aspirantes á ensinanza secundaria.

O 29 de xaneiro de 1925 a JAE enviou ao Ministerio de Instrución Pública un informe, tralo que se inxectaron unhas liñas xerais, que servirían de orientación para implantar o ensaio do Instituto-Escuela. No informe recóllense os resultados dos seis primeiros cursos escolares de ensaios e ponse de relevo que se trata dun centro de experimentación creado para a reforma da Segunda Ensinanza. Era un Instituto con carácter de «laboratorio pedagóxico». A partir do 1 de marzo de 1930, o Instituto-Escuela tivo carácter permanente.

Coa chegada da Segunda República, esta innovación estendeuse a outras cidades. O Ministerio autorizou á Generalitat de Catalunya para organizar en Barcelona un Instituto-Escuela 
semellante ao de Madrid (Decreto de 9/10/1931). Por outro Decreto de 2/3/1932, con Fernando de los Ríos como Ministro de Instrución Pública, creáronse Institutos-Escuela en Valencia e Sevilla. A O.M. de 17/2/1933 creaba o Instituto-Escuela de Málaga. A eles seguiron outros en Barcelona e Xixón. Houbo, ademais, intentos coma o de Granada.

A guerra civil e o franquismo deron ao traste con esta innovadora experiencia.

Xa no período democrático posterior á proclamación da Constitución de 1978, a Ley de Ordenación General del Sistema Educativo (LOGSE, 1990), e disposicións posteriores, coa ampliación da escolaridade obrigatoria a 10 anos (educación básica, 6-16 anos) e as dificultades de transición entre a educación primaria e a secundaria, recuperouse esa iniciativa, a través da creación dos centros públicos integrados de educación primaria e secundaria obrigatoria, incluíndo, no seu caso, tamén a educación infantil (gratuíta, 3-6 anos). Porque nos centros privados (concertados ou non) nunca deixou de haber esa posibilidade, aínda que, con preocupacións e intereses distintos e diferentes casuísticas. Os centros integrados ofrecen indubidables vantaxes, pero tamén presentan dificultades, entre elas o desenvolvemento dos respectivos regulamentos orgánicos (coa presenza de dous xefes de estudos), ou «el desarrollo de las culturas profesionales diferentes» (Andrés Rubia, 2011), concepto ao que lle leva prestado atención Viñao (2002), en canto á cultura escolar dos mestres e dos profesores de secundaria. Non tratamos aquí o tema dos Centros Integrados Públicos de Formación Profesional.

Entre outras experiencias, como é o caso de Aragón, que Fernando Andrés Rubia analiza neste número de Innovación Educativa, «en dos comunidades eminentemente rurales como Galicia y Castilla y León este fue el modelo necesario que arranca la implantación de la LOGSE». En comunidades como Madrid «es un modelo más bien anecdótico, motivado la mayor parte de las veces por cuestiones organizativas y económicas». En Cataluña, «la apuesta data de la Ley de Educación de Cataluña (2009)» (Saray Marqués, 2018).

A prensa tamén se leva feito eco desta problemática, e a través dela é posible realizar un estudo destes centros, con unha metodoloxía que temos utilizado noutras ocasións (Porto Ucha, 2003; Mera Cao, 2014). Así, en Galicia, o modelo CPI foi pensado «para los concellos rurales donde no compensa montar un IES pero tampoco conviene que los alumnos de 12 años pasen horas en el bus para ir a otro concello» (La Voz de Galicia, 30/6/2017).

Con motivo do centenario de creación do Instituto-Escuela (1918-2018) Innovación Educativa pensou na posibilidade de dedicar un monográfico ao estudo desta experiencia, tanto dende o punto de vista histórico educativo, focalizado na análise dos Institutos-Escuela anteriores á contenda civil, como estudando os centros públicos destas características postos en funcionamento nas distintas comunidades autónomas, basicamente coa chegada do novo século, nas súas diversas denominacións e presupostos. Trátase soamente dunha aproximación. Somos conscientes de que o tema merecería un estudo global máis amplo, coa participación das institucións educativas do conxunto das comunidades autónomas do Estado español.

O tema principal deste número da revista Innovación Educativa ocupa, pois, dous tipos de traballos: 


\section{a) Os referidos aos Institutos-Escuela históricos}

Este apartado comprende tres artigos. Un de carácter xeral, de Ángel Serafín Porto Ucha e Raquel Vázquez Ramil, «En el centenario de creación del Instituto-Escuela: Realizaciones educativas de los institucionistas», no que se repasan as iniciativas pedagóxicas da ILE, dedicando especial atención ao Instituto-Escuela de Madrid, que este ano celebra o seu centenario; así mesmo, préstase atención á pegada que os proyectos pedagóxicos institucionistas deixaron en Galicia, con exemplos como a Misión Biolóxica ou as colonias escolares.

Encarnación Martínez Alfaro ofrece, en «Tiempo y memoria del Instituto Escuela de Madrid» unha documentada análise da creación do Instituto-Escuela de Madrid, concretamente a chamada sección Retiro, xunto ao famoso parque, e a súa conversión trala guerra civil en IES Isabel la Católica. Encarnación Martínez Alfaro, catedrática de Xeografía e Historia en dito centro, ten estudado a fondo a documentación histórica existente no mesmo e ofrece tamén a utilización do patrimonio do Instituto-Escuela como recurso didáctico con alumnos da ESO, experiencias sumamente interesantes e que vinculan un pasado esquecido durante moito tempo coa realidade pedagóxica actual máis vibrante.

Patricia Delgado Granados, profesora de Teoría e Historia de la Educación da Universidade de Sevilla, presenta «El Instituto-Escuela de Sevilla (1932-1936): Un proyecto inconcluso de renovación pedagógica en España» e analiza a apertura do Instituto-Escuela na capital hispalense, en tempos da Segunda República, e o seu traumático peche coa guerra civil, como todas as empresas desta índole.

\section{b) Os referidos aos actuais centros públicos integrados de educación primaria e secundaria}

Neste apartado contamos co estudo de Fernando Andrés Rubia, mestre e sociólogo e director das revistas Forum Aragón y Organización y Gestión Educativa, «Impulso y resistencia en la creación de centros integrados en Aragón». Fernando Andrés leva estudado a fondo a cuestión dos centros públicos integrados en Aragón e presenta un estudo moi b en fundamentado sobre as súas posibilidades e tamén os retos que plantexan estes centros, non sempre ben asumidos.

Màrius Martínez Muñoz, profesor de Orientación Profesional na Universidade Autónoma de Barcelona, e Carmina Pinya Salomó, docente e investigadora, contribúen co artigo «Los InstitutosEscuela en Catalunya: recuperando la mejor tradición pedagógica de la República», no que ofrecen unha interesante perspectiva sobre o modelo de centro público integrado de Catalunya, que dende o ano 2009 recupera o nome histórico de Instituto-Escuela, e a súa traxectoria.

O ámbito de Galicia é analizado por Julia $\mathrm{M}^{\mathrm{a}}$ Diz López, membro do Departamento de Pedagoxía e Didáctica da Universidade de Santiago de Compostela, no artigo titulado «Los centros públicos integrados en Galicia. Un modelo a debate», onde se expoñen con claridade os debates que xeran actualmente este tipo de centros na Comunidade Autónoma galega. E nesta liña, pero cun estudo de caso, a profesora Ana $\mathrm{M}^{\mathrm{a}}$ Porto Castro, tamén do Departamento de Pedagoxía e Didáctica da Universidade de Santiago de Compostela, e Isabel Sánchez Manso, ex docente nun 
centro público integrado, presentan «Pasado y presente de un Centro Público Integrado de Galicia», onde analizan o caso do CPI Viaño Pequeno de Trazo (A Coruña). Estes dous artigos referidos a Galicia compleméntanse co estudo de Enelina $\mathrm{M}^{\mathrm{a}}$ Gerpe García, «Panorámica actual de los centros públicos integrados de enseñanza obligatoria en la Comunidad Autónoma de Galicia», incluído na sección de Documentación.

Esperamos, con este número 28 da revista Innovación Educativa, conmemorar o centenario do primeiro Instituto-Escuela, creado pola JAE en Madrid en 1918, e situarnos no presente, analizando a realidade dos centros públicos que pretenden integrar a ensinanza primaria e secundaria nun solo centro, as súas perspectivas de futuro e os retos que suscitan.

\section{REFERENCIAS BIBLIOGRÁFICAS}

Andrés Rubia, F. (2011). Los centros públicos integrados de enseñanza obligatoria: un territorio inexplorado. Fórum Aragón, 3 (octubre), 3-7.

Las claves del conflicto en Educación. El modelo de colegio integrado gusta mucho a las familias, pero no al Estado. La Voz de Galicia, 30/6/2017.

Marqués, S. (2018). Centros integrados: cuando la pública imita a la concertada. El diario de la educación, 8/5/2018.

Mera Cao, F. (2014). O conflito nos centros escolares. Imaxe da conflitividade escolar na prensa. TFG. USC. Facultade de Ciencias da Educación, Dpto. de Didáctica e Organización Escolar. Grao en Educación Primaria. Tutor: Ángel Serafín Porto Ucha.

Porto Ucha, A. S. (2003). La imagen de la conflictividad en la prensa gallega. En E. López-Barajas Zayas, y J. H. Bouché Peris (Coords.), La educación para una cultura de paz: Problemas y perspectivas. Madrid: UNED, pp. 258-262.

Porto Ucha, A. S. (2005). La Institución Libre de Enseñanza y la renovación pedagógica en Galicia. Sada - A Coruña: Ediciós do Castro.

Porto Ucha, A. S. (2011). La Institución Libre de Enseñanza. Un movimiento de renovación pedagógica. En O. Negrín Fajardo, Historia de la Educación Española. Madrid: UNED, pp. 383-427.

Porto Ucha, A. S. y Vázquez Ramil, R. (2015). María de Maeztu. Una antología de textos. Madrid: Dykinson.

Prospecto para el curso de 1885-86, BILE, IX (1885), p. 285.

Programa de la Institución Libre de Enseñanza. BILE, LVIII (1934), pp. 87-94.

Vázquez Ramil, R. (2012). Mujeres y educación en la España contemporánea. La Residencia de Señoritas de Madrid (1915-1936). Madrid: Akal.

Viñao, A. (2002). Sistemas educativos, culturas escolares y reformas. Madrid: Morata.

\section{Lexislación}

Galicia. Consellería de Educación y Ordenación Universitaria. Decreto 7/1999, de 7 de enero (DOG, $n^{\circ} 16$, de 26/01/1999), por el que se implantan y regulan los centros públicos integrados de enseñanzas non universitarias. 